\title{
Práticas de Humanização em Saúde: uma Experiência com Idosos Acometidos de Vestibulopatias
}

\author{
Aprile, Maria Rita; Schulteisz, Thaís S. de Vincenzo; Bilotta, Fernanda Aprile; Kuns, \\ Elisabete \\ Universidade Bandeirante Anhanguera — ritaaprile@hotmail.com
}

Introdução: o conceito de humanização em saúde está sujeito a valores e princípios que regem políticas públicas, práticas de diferentes categorias profissionais, inúmeras modalidades e protocolos de atenção e prevenção à saúde. Apesar dessa diversidade, consolida-se o pressuposto que a humanização das relações em saúde em oposição ao comportamento cartesiano, que distancia os profissionais e pacientes, constitui uma condição que interfere diretamente nos processos de tratamento e de minimização do sofrimento. Objetivo: Investigar as contribuiçõs para a qualidade de vida e inclusão social de idosos em tratamento de vestibulopatias, a partir da convivência com seus pares, em oficinas temáticas, orientadas por princípios de humanização em saúde. Método: Estudo exploratório e descritivo com 62 vestibulopatas, de ambos gêneros, idade entre 60 e 84 anos e diferentes escolaridades, que assinaram termo de consentimento livre e esclarecido. Os dados foram obtidos por meio de questionário de qualidade de vida e registros de observação em oficinas direcionadas à interação social, estimulação da memória, uso de medicamentos, aposentadoria, atividade física e alimentação. Os idosos foram distribuídos em 4 grupos que participaram de 4 oficinas com duração de 3 horas cada. ao todo, foram realizadas 16 oficinas e 48 horas de observação. Resultados: dos distúrbios vestibulares, a tontura foi a queixa predominante (60\%). Houve prevalência de idosos entre 65 e 69 anos (32\%); gênero feminino (80\%) e ensino fundamental completo (67,7\%); 79\% eram aposentados e, desses, $18 \%$ continuavam a trabalhar; $18 \%$ exerciam trabalho improdutivo; $22 \%$ trabalho voluntário; $24 \%$ desempenhavam atividades na família; $19 \%$ buscavam trabalho remunerado e $11 \%$ consideravam as vestibulopatias impeditivas ao trabalho. As caminhadas constituíam a atividade física predominante (60\%) e, assistir televisão, o lazer principal (90\%); 95\% não tinham alimentação balanceada; 34\% desenvolviam atividades que exigiam memória e concentração; 60\% liam jornais, livros e revistas; $69 \%$ participavam de cursos e palestras e $58 \%$ de grupos religiosos; $72 \%$ faziam planos de vida; $77 \%$ não consideravam a morte uma realidade próxima e 30\% usavam antidepressivos. nas Oficinas, os idosos compartilharam: experiências pessoais (tentativa de suicídio, rejeição familiar, depressão etc.) e sentimentos (abandono, inutilidade, não pertencimento social); estabeleceram vínculos de amizades; fortaleceram a autoestima e resgataram o seu papel social, além de se comprometerem com o tratamento em curso e com as práticas de autocuidado (alimentação, higiene, uso adequado de medicamentos etc.). Conclusões: Apoiados em princípios de humanização em saúde, os comportamentos interativos proporcionados pelas Oficinas permitiram a esses idosos estabelecer relações afetivas e solidárias com repercussões no desenvolvimento de: autoestima, sentimento de pertencimento social, tratamento das vestibulopatias, bem estar e qualidade de vida

Aprile, Maria Rita; Schulteisz, Thaís S. de Vincenzo; Bilotta, Fernanda Aprile; Kuns, Elisabete. Práticas de Humanização em Saúde: uma Experiência com Idosos Acometidos de Vestibulopatias. In: Anais do Congresso Internacional de Humanidades \& Humanização em Saúde [= Blucher Medical Proceedings, num.2, vol.1]. São Paulo: Editora Blucher, 2014. ISSN 2357-7282

DOI 10.5151/medpro-cihhs-10769 